\title{
Application of Polymer Phospholipid Matrix for Closing Open Wounds on Oral Mucosa
}

\author{
DOI: $10.17691 / \mathrm{stm} 2016.8 .1 .08$
}

Received Novenber 10, 2015

D.A. Ryabova, MD, PhD, Assistant, Department of Surgical Stomatology and Maxillofacial Surgery;

N.Y. Orlinskaya, MD, DSc, Professor, Department of Pathologic Anatomy;

S.N. Tsybusov, MD, DSc, Professor, Head of the Department of Operative Surgery and Topographic Anatomy, Vice-Rector for Academic Affairs;

N.E. Homutinnikova, MD, PhD, Associate Professor, Department of Surgical Stomatology and Maxillofacial Surgery;

R.D. Lapshin, MD, PhD, Associate Professor, Head of the Experimental Modeling Department, Central Research Laboratory;

E.A. Durnovo, MD, DSc, Professor, Head of the Department of Surgical Stomatology and Maxillofacial Surgery

Nizhny Novgorod State Medical Academy, 10/1 Minin and Pozharsky Square, Nizhny Novgorod, 603005, Russian Federation

The aim of the investigation was to assess the possibilities of application of the polymer matrix made from Reperen material for closing open wound surface on the mucous membrane of the oral cavity.

Materials and Methods. Experimental investigation was carried out on 15 Chinchilla rabbits. Half of the created defect on the hard palate mucous membrane healed under the Reperen polymer matrix, and the other half healed by secondary intention. The results of the histological and cytological examination were assessed on day 3, 5, and 7.

Results. The area of granulation and connective tissue in the specimens of mucosa, healing without the Reperen matrix on day 5 amounted to $25.0 \pm 1.2$ and $15.0 \pm 1.1 \%$, and on day $7-15.0 \pm 1.2$ and $25.0 \pm 1.7 \%$, respectively. Meanwhile, in the specimens of mucous membrane, healing under the Reperen polymer matrix, their values have essentially changed: they were $25.0 \pm 1.2$ and $20.0 \pm 1.1 \%$ on day 3 , and $10.0 \pm 1.3$ and $40.0 \pm 1.7 \%$ on day 7 .

Conclusion. The Reperen polymer matrix promotes intensification of the local regenerative processes in the wound and can be used for closing large open wound surfaces on the mucous membrane of the oral cavity. Reperen.

Key words: defects of the oral cavity mucous membrane; cicatricial deformity; regeneration of oral mucosa; polymer phospholipid matrix;

The outcomes of surgical interventions in the oral cavity are not always satisfactory and depend on the postoperative management of the wound. Even smallsize traumas, defects and lesions cause surgeons to perform extensive operative interventions due to anatomical structure of the maxillofacial area in general and oral cavity in particular [1]. Radical operations on soft tissues of the oral cavity often require removal of large tissue volumes, application of donor zone and formation of postoperative defects demanding their onestage closure and wound protection.

Healing of open wound surfaces on the oral mucosa runs usually by secondary intention due to the lack of adjacent local tissues. In this case constant traumatic effect and bacterial contamination of the wound occurs, causing a change in the tissue volume in the postoperative region and formation of the deforming scar tissue [2]. It frequently results in the alterations of the oral cavity architectonics, reduction of the vestibule, as well as impediment to further orthopedic treatment [3-6].

Traditional methods of open wound management (under iodoform turunda, Alvogyl, TachoComb, open management of wound surface, application of approximating sutures) are accompanied in the majority of cases by pain, bacterial infections, bleeding, and later by forming cicatricial changes.

Application of a connective-tissue pedicle flap [7-9] and free palatal flap (free gingival graft, free connectivetissue graft) are the most common methods of open wound closure on the oral mucosa. They allow the

For contacts: Dariya A. Ryabova, e-mail: da-mochalova@mail.ru 
surgeons to achieve good results, but have some drawbacks as well, the main disadvantage being the necessity to make the operation on the donor site [10, 11]. After autograft removal an open wound surface is left on the palate, which heals by second intention. Postoperative course, accompanied by significant discomfort for patients, limits the application of these methods in the surgical practice in spite of the uniqueness of the given regenerative material.

Though there are a lot of conservative and surgical methods of treating inflammatory and destructive processes in the oral cavity, damaged tissues and their original structure and functions are not always amenable to complete restoration. At the current stage of surgical stomatology development new materials and techniques with more universal feasibilities and predictable outcomes, application of which will reduce negative effects of postoperative wound healing by second intention, are being actively searched.

It should be noted, that regeneration of the oral mucous membrane requires constant replacement of one population of cells by the others, specific for the connective tissue, which contributes to the decrease of the necrosis zone in the wound area. A marked inflammatory reaction in this case activates wound healing by secondary intention, but is always accompanied by migration of macrophages and creates favorable conditions for adhesion of microbes [12-16]. In this connection, data on application of synthetic materials, which enable isolation of postoperative defects in the oral cavity, protection of the wound surface and optimization of the wound healing, are of great interest. These materials do not possess antigen foreignness and make it possible to close defects of any configuration regardless of the structure and shape of the wounded area.

One of such material is Reperen (Reper NN, Russia) [17]. This material is elastic, i.e. it is capable to take any shape without any folds and stretching, and lacks residual deformation. It is highly resistant to biologically active media, oxidative processes and the processes of adsorption of proteins on the surface, helps to prevent formation of a coarse connective tissue capsule.

Presently, there is enough data on the application of this material for closing wound surfaces in various branches of medicine such as general surgery, ophthalmosurgery, thoracoplasty, maxillofacial surgery and neurosurgery [18-27].

Such a wide application of the Reperen polymer material and its characteristics made its application attractive in surgical stomatology to isolate wound surface after surgical treatment in order to optimize the process of healing and protect the wound surface.

The aim of investigation was to assess the possibility of using the Reperen polymer material for closing open wounds on oral mucosa on the basis of the experimental data.

Materials and Methods

Physico-chemical properties of the Reperen polymer matrix. Reperen polymer material represents a cross-linked polymer from oligomers of metacryl group. It is synthesized according to one-stage technology (monomer $\rightarrow$ end product), which prevents inclusion of foreign matters. The polymer material is manufactured by frontal photopolymerization in quasi-closed moulds of preset geometry and dimensions in order to produce the necessary item.

Owing to its well-known properties the Reperen polymer has been chosen for the development of a matrix, designated for closing open wounds in the oral cavity and regeneration of oral mucous membrane [28].

The developed matrix is a double-layer nonperforated film. One layer has a mesh structure with a relief pattern, occupying $10-90 \%$ of the matrix area, as high as half the matrix thickness, and with a reinforcing ring element (with 0.7-2.0 mm inner diameter, and 0.2-1.0 $\mathrm{mm}$ wide). The second layer is solid providing firm adherence of the matrix to the wound surface.

A distinctive feature of the given polymer membrane (matrix) is a layer, from saturated carbohydrates formed on its surface with a chain length of 8-18 carbon atoms, oriented mainly towards the surface of the plate. Hydrophobic ends face the wound surface and absorb lipids contained in it in such a way that hydrophobic ends of lipids face the hydrophobic ends of the matrix, while hydrophilic ends are directed outwards. Hydrophilic lipid ends absorb, in their turn, proteins from the wound surface. Thus, a surface similar to that of the cellular membrane is reproduced. A solution like this makes a high adhesion of the stem (mesenchymal) cells to the matrix possible, providing high density of cells attachment to the given matrix, and also stimulation of proliferation and differentiation of the native tissue, and growth of new forming connective tissue fibers.

This matrix causes no allergic reactions, is resistant to biologically active liquids, adheres well to the wound and prevents its own movements, resulting in generation of stable granulations.

Its application precludes the development of inflammatory processes and cicatricial tissue formation, as epithelization of the wound surface runs without deformation of the general tissue volume and without any structural changes. The polymer matrix is biologically inert, causes no inflammatory reactions and capillary growth in adjacent tissues or rejection, which allows its application for acceleration of wound surface healing and, therefore, increase of the efficacy of surgical treatment of the oral cavity.

Experimental study. The experimental model included creation of the defect of the oral mucous membrane on the animal's hard palate. Such condition was similar to the common clinical situation occurring in surgical interventions, demanding the application of a free gingival autograft, which is inevitably accompanied by the wound surface formation on the hard palate.

The experiment was carried out on 15 Chinchilla rabbits of both genders weighing $3,750-4,000 \mathrm{~g}$. The investigation plan included three stages of observations: on day $3,5,7$. Five rabbits participated at each stage of the investigation. 

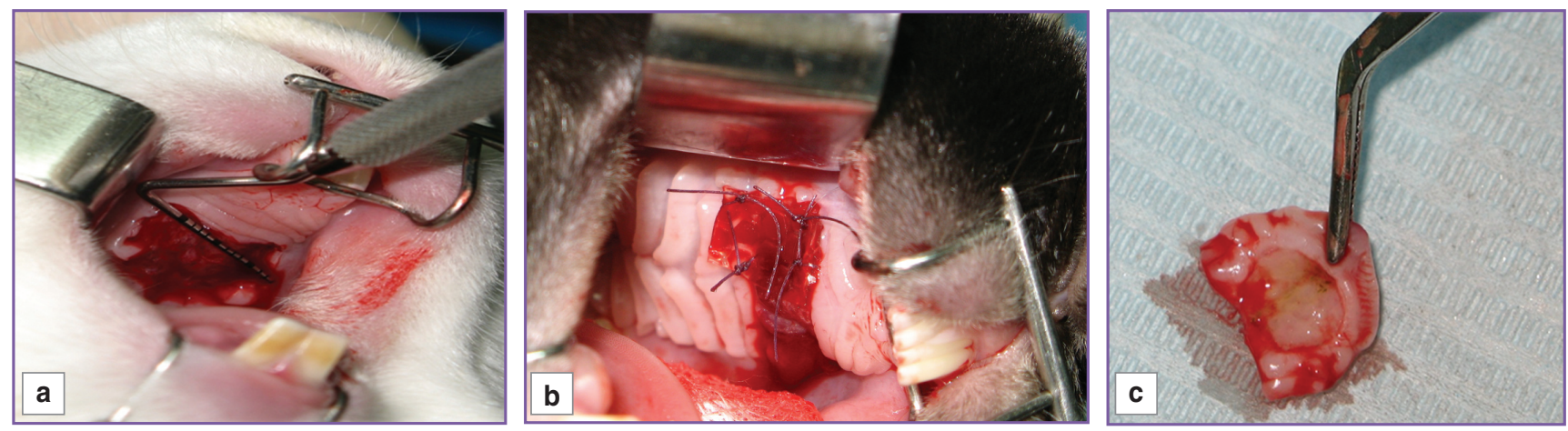

Figure 1. Experiment procedure: (a) measurement of the created defect on the hard palate; (b) Reperen membrane is fixed by sutures to the half of the defect; (c) taking bioptate after the previously performed operation

Experiment procedure. The work was performed in accordance with ethical principles established by European Convention for the Protection of Vertebrata used for Experimental and other Scientific Purposes (the Convention was passed in Strasburg, March, 18, 1986, adopted in Strasburg, June, 15, 2006) and approved by Ethics Committee of Nizhny Novgorod State Medical Academy. Connective tissue autograft of a certain size and shape (Figure 1 (a)) was taken under general anesthesia of sodium barbiturate $(30 \mathrm{mg} / \mathrm{kg}$, intravenously) and auxiliary infiltration anesthesia of 1:100,000 Ultracain solution (containing adrenaline). Then the edges of a sterile pack with Reperen matrix were cut after treating it with $70 \%$ alcohol and the matrix was removed from the pack with sterile forceps. A graft of the required size and shape equal to $1 / 2$ of the obtained defect was cut out with scissors. The Reperen was applied to the defect on the hard palate so that it covered half of the wound surface overlapping the wound margins by $3 \mathrm{~mm}$, and fixed by interrupted suture using Vicryl 5-0 suture material attached to an atraumatic needle (Figure 1 (b)). The needle was introduced precisely to the center of the reinforcing ring. The other half of the wound surface healed by secondary intention (traditional method) without using any additional materials.

The animals were withdrawn from the experiment on day 3,5 , and 7 after autograft collection by means of sodium barbiturate injection ( $30 \mathrm{mg} / \mathrm{kg}$, intravenously) with further introduction of air emboli to the bloodstream via veins. During the operation a full layer of connective tissue autograft of the hard palate was collected (in the area of the previously formed defect) taking partially healthy connective tissue from the wound margins (Figure 1 (c)).

Then all bioptates, obtained on day 3, 5, 7 after the collection of the full-layer autograft of the hard palate mucosa with the area of experimentally created wound surface over a full wound extension, underwent histological examination. Nikon 1001 microscope $(\times 90, \times 40, \times 15$ lenses and $\times 15$ eyepiece) was used for morphometric processing and creation of video archive of the obtained material. The image analyzing system, consisting of ECLIPS (Nikon, Germany) light transmission microscope, Pentium IV IBM computer, DS color digital camera, DS-U1 (Nikon) control unit and FST-2U software, was used for computer analysis of the histological specimens. To assess the pathological processes in the tissues, morphometric study for the presence of lymphohistiocytic (round cell) and leucocytic (neutrophl) infiltration was performed, the areas of necrosis and granulation and connective tissue were determined.

Data was statistically processed by Fisher analysis (for the groups less than 15 in number). The total quantity of the histological specimens analyzed using traditional methods amounted to 30 [29-32].

The intensity of wound epithelization was assessed by cytologic technique taking impression smears from the wound on day 3,5 , and 7 after removal of the Reperen matrix from the experimentally created defect on the hard palate. The smears were placed on the degreased slides, distributed uniformly over the surface with a spatula, and stained with azure and eosin according to Romanovsky-Gimse. Smear review and cellular elements counting were conducted using Nikon 1001 microscope, $\times 90$ lens, $\times 15$ eyepiece. A total number of 30 smears from the postoperative wound were analyzed [33, 34].

Results and Discussion. On day 3 after the operation extensive tissue necrosis with a marked neutrophilic infiltration, vascular hyperemia and edema were noted in bioptates of the hard palate mucous membrane under histological examination in a rabbit without the Reperen matrix in the zone of the previously created defect. There was no evidence of granulation or connective tissue development (Figure 2 (a)). The histological picture of the mucous membrane, where the Reperen matrix was applied, showed small regions of necrosis, moderate neutrophilic and lymphohistiocytic infiltration, hemorrhages, hyperemia and the beginning of granulation in single fields of vision (Figure $3(a)$ ).

On day 5 after the operation the histological examination of the mucous membrane specimens of the wound healing without the Reperen matrix revealed two-fold reduction of the necrosis area and decrease of neutrophilic infiltration. In some fields of vision generation 

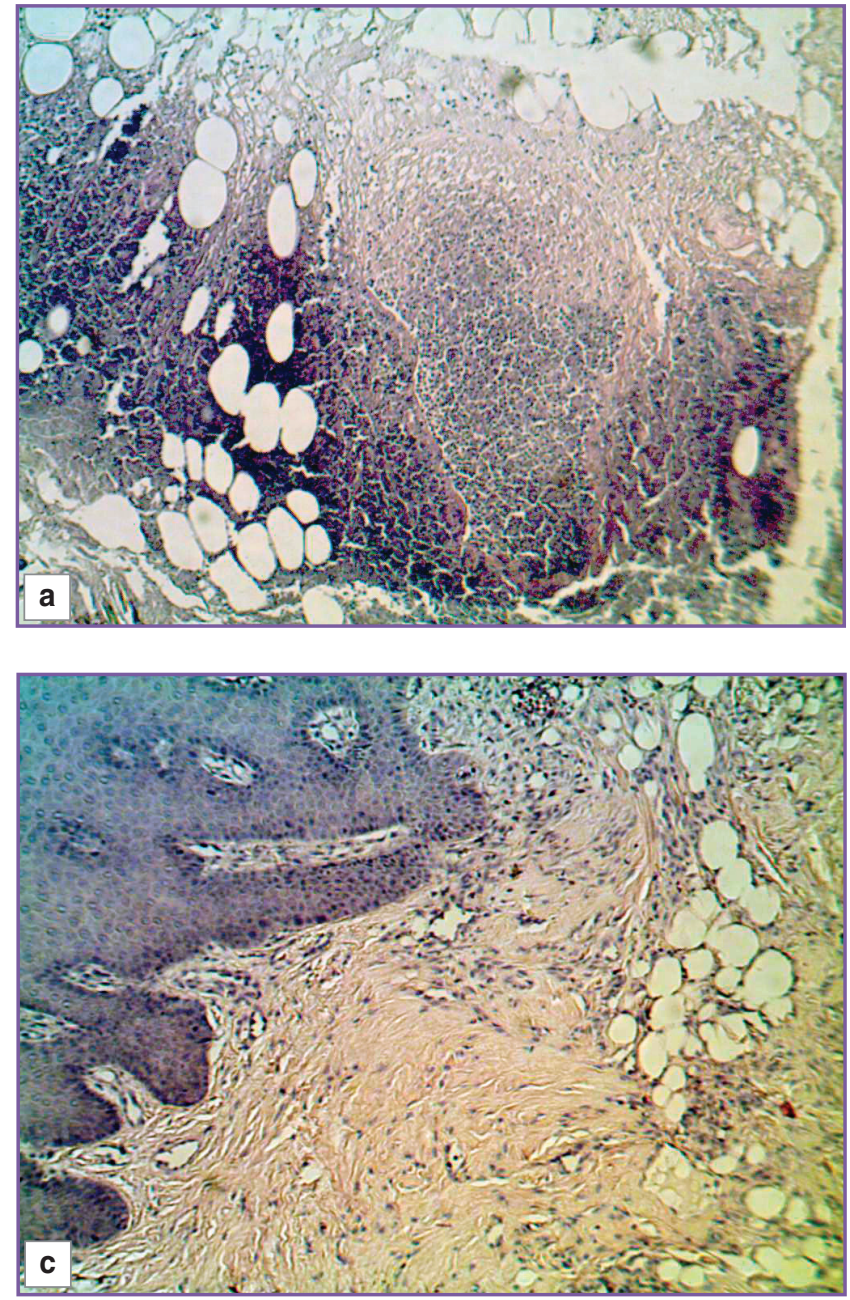

of granulation tissue and small regions of connective tissue were seen (Figure 2 (b)). On day 5 the picture of the hard palate mucous membrane healing under the matrix showed complete disappearance of neutrophils, single hemorrhages, and active formation of granulation and connective tissue (Figure 3 (b)).

On day 7 after the operation total lack of neutrophilic infiltration, development of granulation tissue and formation of connective tissue, as well as moderate round cell infiltration were noted in the zone, which healed without the Reperen matrix (Figure 2 (c)).

The condition of the mucous membrane on day 7 in the zone healing under the Reperen matrix corresponded to the normal membrane with the development of a newly generated granulation and subtle fibrous connective tissue in the submucosal layer (Figure 3 (c)).

The analysis of regenerative process dynamics in case of application of the Reperen polymer matrix and without it on the basis of the morphometric method of investigation of the wound surface cellular condition at various stages of postoperative observation showed that the process of regeneration of the mucous membrane healing under the polymer matrix ran significantly quicker (Tables 1, 2).

When the Reperen matrix was used, intensity of

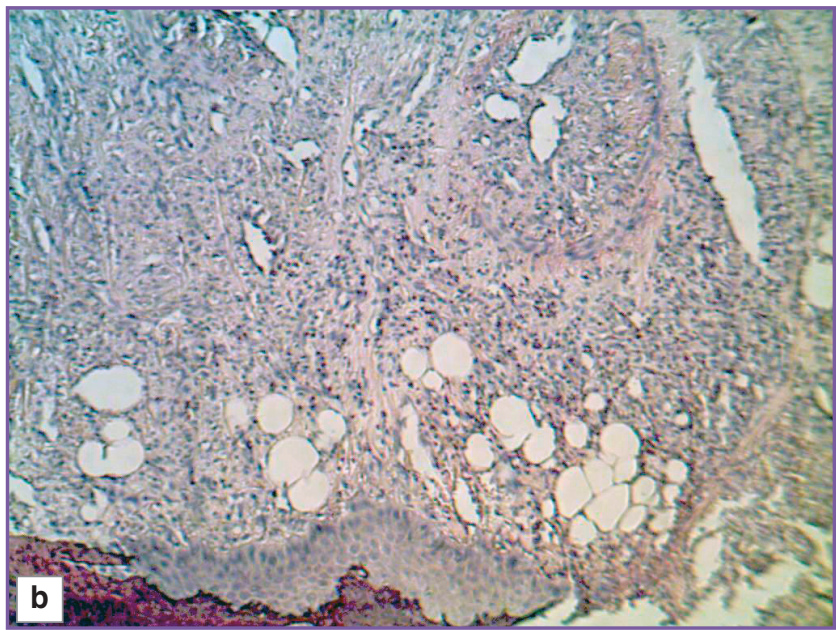

Figure 2. Morphologic picture of the histological specimen of the hard palate mucous membrane in the region healing without Reperen polymer membrane (hematoxylin and eosin; $\times 200$ ): (a) on day 3; (b) on day 5; (c) on day 7

the inflammatory reaction on day 3 decreased due to the reduction of neutrophil quantity, and by day 5 they disappeared completely. Formation of granulation tissue also initiated on day 3 . In the histological preparations of the mucous membrane, which healed without the polymer matrix, necrotic events apparent on day 3 and reducing by half by day 5 , long-term inflammatory process and a small quantity of the developed granulation and connective tissue were observed.

Cytologic investigation and comparison of the impression smears taken from the wound surface healing under the Reperen matrix and without it showed significant differences in the terms of epithelization. Massive hemorrhages and a large number of erythrocytes were revealed on day 3 in the impression smears taken from the wounds, which healed under the polymer membrane and without it.

In the smears from the wound healing open a large number of erythrocytes were preserved on day 5 , while in the specimens from the wound healing under the Reperen matrix increase of differentiated epithelium cells was noted mainly at the expense of intermediate epitheliocytes.

On day 7 single epitheliocytes were found in the smears from the wound healing without the matrix, 

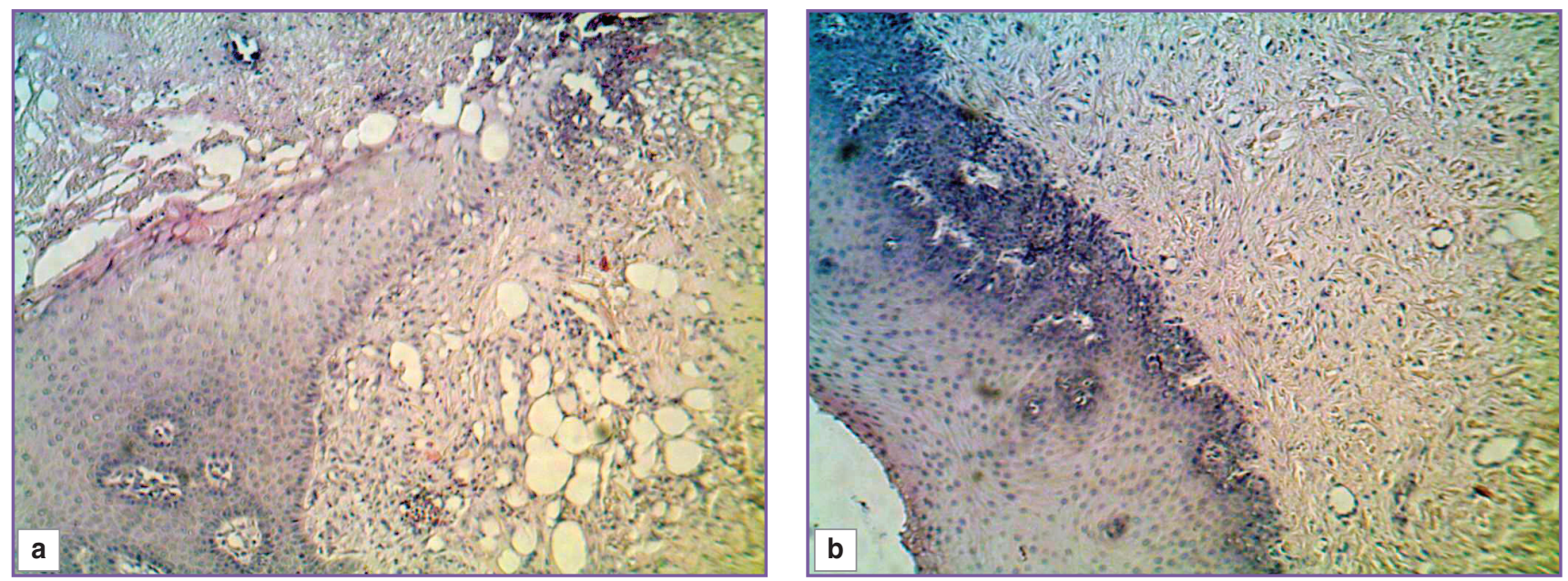

Figure 3. Morphologic picture of the histological specimen of the hard palate mucous membrane in the region healing with Reperen polymer membrane (hematoxylin and eosin; $\times 200$ ): (a) on day 3; (b) on day 5; (c) on day 7

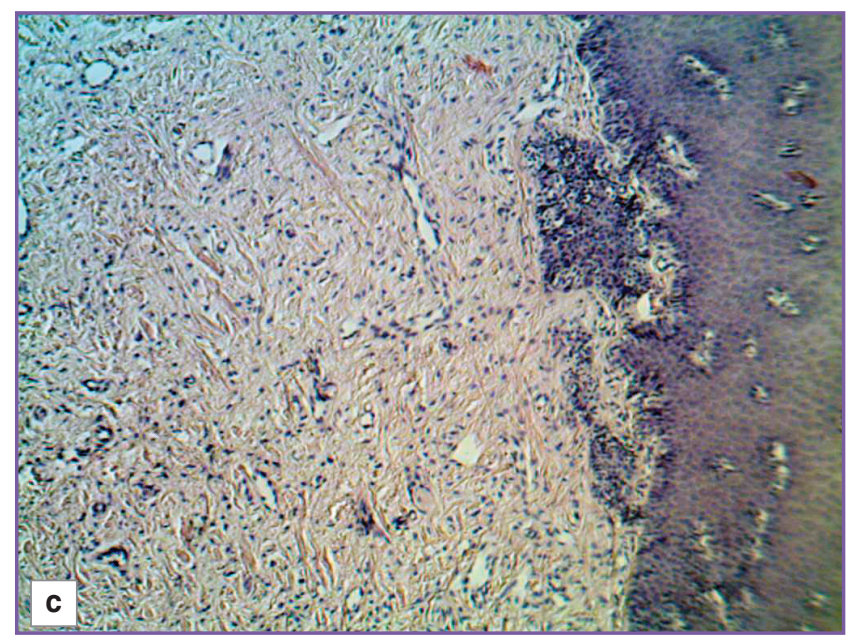

Table 1

Morphometric characteristic of the wound surface healing without Reperen polymer matrix (\%)

\begin{tabular}{lccc}
\hline \multicolumn{1}{c}{ Morphologic criteria } & Day $\mathbf{3}(\mathbf{n}=\mathbf{5})$ & Day $\mathbf{5}(\mathbf{n}=\mathbf{5})$ & Day $\mathbf{7}(\mathbf{n}=\mathbf{5})$ \\
\hline Necrosis area & $50.0 \pm 1.7^{*}$ & $20.0 \pm 1.4^{*}$ & 0 \\
\hline Neutrophil quantity & $35.0 \pm 1.2^{*}$ & $8.0 \pm 1.7^{*}$ & 0 \\
\hline Round cell element quantity & $10.0 \pm 1.3$ & $20.0 \pm 1.3^{*}$ & $15.0 \pm 1.3^{*}$ \\
\hline Granulation tissue area & 0 & $25.0 \pm 1.2$ & $15.0 \pm 1.2^{*}$ \\
\hline Connective tissue area & 0 & $15.0 \pm 1.1^{*}$ & $25.0 \pm 1.7^{*}$ \\
\hline
\end{tabular}

* statistically significant difference of values with the data obtained when the matrix was used, $p \leqslant 0,05$.

Table 2

Morphometric characteristic of the wound surface healing with Reperen polymer matrix (\%)

\begin{tabular}{lccc}
\hline \multicolumn{1}{c}{ Morphologic criteria } & Day $\mathbf{3}(\mathbf{n}=\mathbf{5})$ & Day $\mathbf{5}(\mathbf{n}=\mathbf{5})$ & Day $\mathbf{7}(\mathbf{n}=\mathbf{5})$ \\
\hline Necrosis area & $30.0 \pm 1.7$ & 0 & 0 \\
\hline Neutrophil quantity & $15.0 \pm 1.3$ & 0 & 0 \\
\hline Round cell element quantity & $12.0 \pm 1.2$ & $10.0 \pm 1.3$ & 0 \\
\hline Granulation tissue area & 0 & $25.0 \pm 1.2$ & $10.0 \pm 1.3$ \\
\hline Connective tissue area & 0 & $20.0 \pm 1.1$ & $40.0 \pm 1.7$ \\
\hline
\end{tabular}



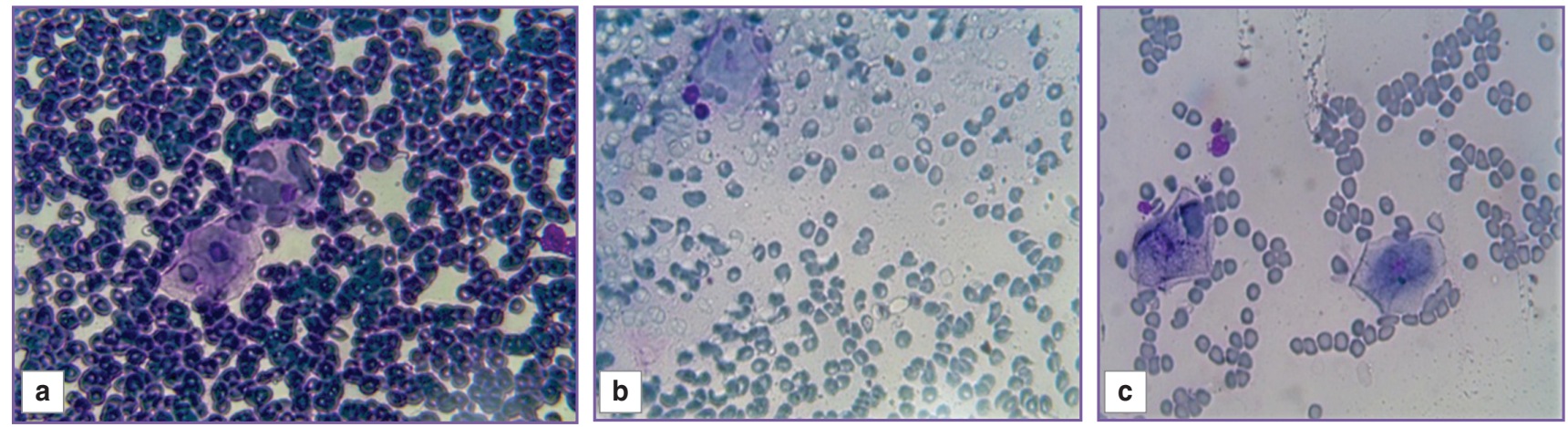

Figure 4. Cytologic investigation of the impression smears taken from the wound healing open without Reperen polymer membrane (azure and eosin staining according to Romanovsky-Gimse; $\times 400$ ): (a) on day 3; (b) on day 5; (c) on day 7
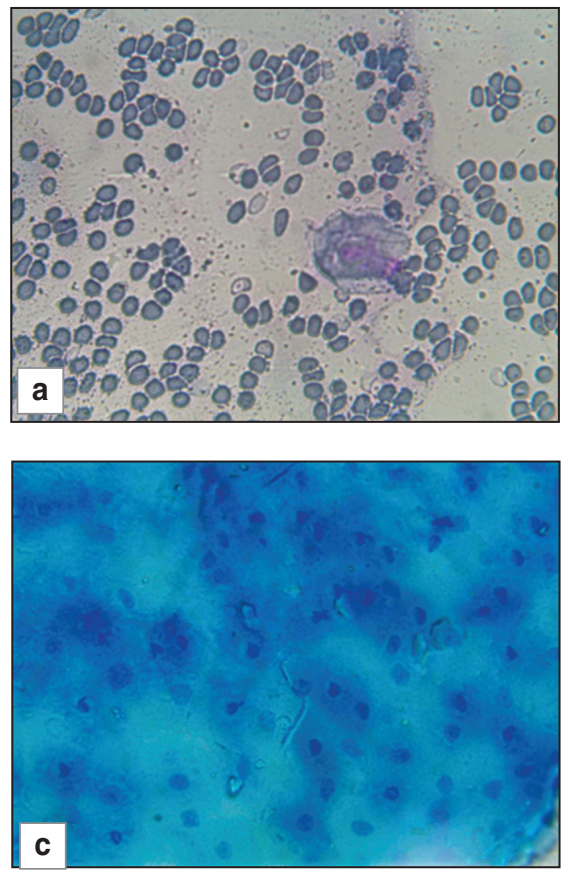

meanwhile in the preparations collected from the wound, which healed under the matrix, epithelization of the wound surface took place owing to the active formation of epitheliocytes (Figures 4, 5).

Thus, the analysis of morphological and cytological investigation findings has convincingly proved the advantages of using Reperen polymer matrix for closing wound surface in the oral cavity, manifested by the decrease in the number of days necessary for the formation of the submucosal layer, i.e. formation of granulation and connective tissue. The process of wound epithelization also goes on much more successfully: 2 times quicker compared to the open wound management due to the active formation of intermediate epitheliocytes.

Conclusion. The Reperen polymer matrix promotes intensification of the local regenerative processes in the wound and may be used for closing extensive open wound surfaces on the mucous membrane of the oral cavity.

Study Funding and Conflicts of Interest. This study

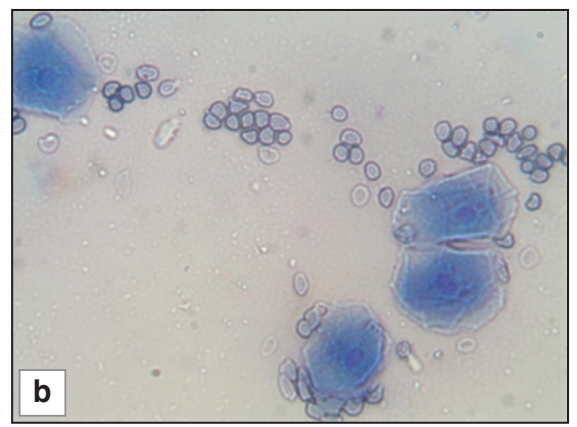

Figure 5. Cytologic investigation of the impression smears taken from the wound healing under Reperen polymer membrane (azure and eosin staining according to Romanovsky-Gimse; ×400): (a) on day 3; (b) on day 5 ; (c) on day 7

was not supported by any financial sources and there is no topic specific conflicts of interest related to the authors of this study.

\section{References}

1. Blednov A.V. Perspective trends in the development of new surgical dressings. Novosti khirurgii 2006; 14(1): 9-19.

2. Shinkevich D.S. Osobennosti zazhivleniya posleoperatsionnykh ran myagkikh tkaney litsa $v$ oblasti preddveriya rta, izolirovannykh silikonovymi membranami. Avtoref. dis. ... kand. med. nauk [Healing of postoperative wounds of facial soft tissues in the oral vestibular area isolated by silicon membranes. PhD Thesis]. Moscow; 2008.

3. Kolsanov A.V. Kompleksnoe lechenie ranevykh defektov kozhi i myagkikh tkaney razlichnoy etiologii s primeneniem kletochnykh kul'tur i biopokrytiy (eksperimental'no-klinicheskoe issledovanie). Avtoref. dis. ... dokt. med. nauk [Complex treatment of skin and soft tissue wound defects of various etiology using cell cultures and biocoatings ( experimental and clinical study). DSc Thesis]. Samara; 2003. 
4. Carnio J., Hallmon W.W. A technique for augmenting the palatal connective tissue donor site: clinical case report and histologic evaluation. Int J Periodontics Restorative Dent 2005; 25(3): 257-263.

5. Hofmänner P., Alessandri R., Laugisch O., Aroca S., Salvi G.E., Stavropoulos A., Sculean A. Predictability of surgical techniques used for coverage of multiple adjacent gingival recessions - a systematic review. Quintessence Int 2012; 43(7): 545-554.

6. Mansouri S.S., Ayoubian N., Manouchehri M.E. A comparative 6-month clinical study of acellular dermal matrix allograft and subepithelial connective tissue graft for root coverage. J Dent (Tehran) 2010; 7(3): 156-164.

7. Gasparini D.O. Double-fold connective tissue pedicle graft: a novel approach for ridge augmentation. In J Periodontics Restorative Dent 2004; 24(3): 280-287.

8. Calesini G., Micarelli C., Coppè S., Scipioni A. Edentulous site enhancement: a regenerative approach for the management of edentulous areas. Part 1. Pontic areas. Int $J$ Periodontics Restorative Dent 2008; 28(5): 517-524.

9. Kuru B., Yıldırım S. Treatment of localized gingival recessions using gingival unit grafts: a randomized controlled clinical trial. J Periodontol 2013; 84(1): 41-50, http://dx.doi. org/10.1902/jop.2012.110685.

10. Kobayashi K., Suzuki T., Nomoto Y., Tada Y., Miyake M., Hazama A., Omori K. Potential of heterotopic fibroblasts as autologous transplanted cells for tracheal epithelial regeneration. Tissue Eng 2007; 13(9): 2175-2184, http://dx.doi.org/10.1089/ ten.2007.0008.

11. Mahajan A. Treatment of multiple gingival recession defects using periosteal pedicle graft: a case series. J Periodontol 2010; 81(10): 1426-1431, http://dx.doi. org/10.1902/jop.2010.100134.

12. Lukanina K.I. Razrabotka nauchnykh i tekhnologicheskikh osnov sozdaniya perevyazochnykh sredstv iz biodestruktiruemykh i biosovmestimykh voloknistykh materialov na osnove polilaktida. Avtoref. dis. ... kand. tekh. nauk [Development of scientific and technological foundation for creation of dressing materials from biodestructable and biocompatible fibrous materials based on polylactide. PhD Thesis]. Moscow; 2011.

13. Rokhvager I.S., Moroz B.T. Effect of the oral vestibular depth on the parodontal tissue state. Institut stomatologii 2000; 4(9): 38-39.

14. Kapoor S., Patel S.A., Kartan S. Tolerance-like mediated suppression by mesenchymal stem cells in patients with dust mite allergy-induced asthma. J Allergy Clin Immunol 2012; 129(4): 1094-1101, http://dx.doi.org/10.1016/j.jaci.2011.10.048.

15. Kim H.S., Kim N.H., Kim J., Cha I.H. Inducing reepithelialization in skin wound through cultured oral mucosal keratinocytes. J Korean Assoc Oral Maxillofac Surg 2013; 39(2): 63-70, http://dx.doi.org/10.5125/jkaoms.2013.39.2.63.

16. Mahdavishahri N., Moghatam Matin M., Fereidoni M., Yarjanli Z., Banihashem Rad S.A., Khajeh Ahmadi S. In vitro assay of human gingival scaffold in differentiation of rat's bone marrow mesenchymal stem cells to keratinocystes. Iran J Basic Med Sci 2012; 15(6): 1185-1190.

17. Treushnikov V.M. Basic principles of biocompatible implant manufacturing. Nizhegorodskie vedomosti meditsiny 2007; 6: 46-55.

18. Belov A.I., Cherekaev V.A., Reshetov I.V., Kapitanov D.N., Vinokurov A.G., Zaytsev A.M., Bekyashev A.Kh. Calvarium defect plasty after removal of craniofacial tumors. Voprosy neyrokhirurgii im. N.N. Burdenko 2001; 4: 5-9.
19. Durnovo E.A., Khomutinnikova N.E., Mishina N.V., Trofimov A.O. The peculiarities of the reconstruction of the walls of orbital cavity during the treatment of traumatic damages of facial skeleton. Meditsinskiy al'manakh 2013; 5: 159-161.

20. Krupko A.V., Bogos'yan A.B., Krupko M.S. Use of "Reperen" polymer meshes in surgical treatment of pectus excavatum. Travmatologiya $i$ ortopediya Rossii 2014; 3(73): 69-75.

21. Tikhomirov S.E. Plastika defektov svoda cherepa plastinami «Reperen» (eksperimental'no-klinicheskoe issledovanie). Avtoref. dis. ... kand. med. nauk [Calvarium defect plasty with "Reperen" plates (experimental and clinical study). PhD Thesis]. Nizhny Novgorod; 2011.

22. Tikhomirov S.E. Application of reperen miniplate for minor calvarium defect plasty in intracerebral hematoma removal. Sovremennye tehnologii v medicine 2015; 7(2): 198-201, http:// dx.doi.org/10.17691/stm2015.7.2.23.

23. Tikhomirov S.E., Tsybusov S.N., Kravets L.Ya., Fraerman A.P., Balmasov A.A. Plasty of the base of the skull defects and dura mater with the Reperen's new polymer material. Sovremennye tehnologii v medicine 2010; (2): 6-11.

24. Khodak V.A., Petrov V.V., Dvornikov A.V., Mironov A.A., Baburin A.B., Parshikov V.V., Tsybusov S.N. The possibilities and advantages of sutureless plasty of abdominal wall using different synthetic meshes in experimental study. Sovremennye tehnologii v medicine 2012; (2): 31-36.

25. Uspenskiy I.V. "Reperen" polymer meshes. Nizhegorodskie vedomosti meditsiny 2006; 1: 8-9.

26. Khomutinnikova N.E., Orlinskaya N.Yu., Tsybusov S.N., Durnovo E.A., Mishina N.V. Clinical and morphological assessment of reparative regeneration of the orbit bone tissue using polymer implants in experiment. Morfologicheskie vedomosti 2015; 1: 68-74.

27. Shesterickov A.A., Lalov Yu.V., Fomin P.A., Uspensky I.V. Hermetization of the turkish saddle fundus with the "ReperenST" synthetic implant in a combined treatment of the chiasmal and sellar area tumors. Sovremennye tehnologii $v$ medicine 2011; (1): 6-10.

28. Tsybusov S.N., Durnovo E.A., Khomutinnikova N.E., Treushnikov V.M., Viktorova E.A., Treushnikov V.V., Sorokina O.V. Matritsa dlya regeneratsii myagkikh tkaney [Matrix for soft tissue regeneration]. Patent RF 2526182. 2014.

29. Bozo I.J., Deev R.V., Pinaev G.P. Is «fibroblast» a specialized cell or a functional condition of mesenchymal cells derivatives. Tsitologiya 2010; 52(2): 99-109.

30. Bykov B.L. Tsitologiya $i$ obshchaya gistologiya (funktsional'naya morfologiya kletok i thaney cheloveka) [Cytology and general histology (functional morphology of human cells and tissues)]. Saint Petersburg: SOTIS; 2007.

31. Orlov A.A., Grigoryan A.S., Marinicheva I.G., Ippolitov V.P., Karmen N.B., Mayevsky E.I. Perftoran in healing of soft and osseous tissues in rats. Rossiyskiy stomatologicheskiy zhurnal 2004; 3: 6-10.

32. Bykov V.L. Tissue and cellular protective mechanisms of oral mucosa. Morfologiya 1996; 6: 14-19.

33. Bochkov N.P., Nikitina V.A. Cytogenetics of human stem cells. Molekulyarnaya meditsina 2008, 3. 40-47.

34. Mochatova D.A. Eksperimental'no-klinicheskoe izuchenie osobennostey regeneratsii slizistoy obolochki polosti rta $s$ ispol'zovaniem polimernoy membrany. Avtoref. dis. ... kand. med. nauk [Experimental and clinical study of oral mucosa regeneration using polymer membrane. PhD Thesis]. Nizhny Novgorod; 2015. 